\title{
Factors affecting fluctuations in China's aquatic product exports to Japan, the USA, South Korea, Southeast Asia, and the EU
}

\author{
Miao Miao ${ }^{1} \cdot$ Huang Liu $^{1}$ (D) . Jun Chen ${ }^{1}$
}

Received: 18 January 2021 / Accepted: 31 July 2021/Published online: 17 August 2021

(c) The Author(s), under exclusive licence to Springer Nature Switzerland AG 2021

\begin{abstract}
Seafood has important health benefits, and the growing demand for aquatic products has stimulated rapid trade development. Using 2000-2018 data from the UN Comtrade Database, this study first introduced the export scale, product structure, and market distribution of China's aquatic products. Then, using an extended constant market share model, we investigated the factors affecting fluctuations in China's aquatic product exports to the USA, Japan, South Korea, the Association of Southeast Asian Nations (ASEAN), and the European Union (EU). Import demand was found to be the most important factor affecting China's aquatic product exports. Moreover, China's export structure and market distribution for aquatic products have become increasingly consistent with global demand. In recent years, China's aquatic product competitiveness has declined while its market destinations have diversified. Regarding China's aquatic product types, the main focus has been on labor- and resource-intensive products with low competitiveness. More recently, however, China's competitiveness of product types 0371 and 0372 (Standard International Trade Classification) has been improving in the world market. To further develop China's aquatic product exports, policy should aim to maintain the fisheries ecosystem, encourage seafood operators to adopt good practices, increase investment in science and technology, overcome technical barriers to trade, strengthen research on the needs, preferences, and requirements of major importing countries, expand domestic demand, and strengthen international cooperation.
\end{abstract}

Keywords Aquatic products $\cdot$ Seafood $\cdot$ Export $\cdot$ Constant market share $\cdot$ China

Handling Editor: Dr. Gavin Burnell

Huang Liu

liuhuang@fmiri.ac.cn

Miao Miao

miaomiao@fmiri.ac.cn

1 Fishery Machinery and Instrument Research Institute of Chinese Academy of Fishery Sciences, Shanghai 200092, the People's Republic of China 


\section{Introduction}

Seafood contains many amino acids, fats, vitamins, and minerals that are important components of a healthy diet. It is also an indispensable supplement to nutritionally deficient cereal-based diets, especially for populations in Asia and parts of Africa. Seafood demand has steadily risen in tandem with population growth and improved living standards. During the period 1961-2017, the average annual growth rate of total fish consumption was $3.1 \%$, outpacing the annual population growth rate (1.6\%), and per capita fish consumption rose from $9.0 \mathrm{~kg}$ (live-weight equivalent) in 1961 to $20.3 \mathrm{~kg}$ in 2017 (FAO 2020a). This growing demand for seafood stimulated the rapid development of trade. From 1976 to 2018, the value of global fish-related exports increased at an annual rate of $8 \%$ in nominal terms; by 2018, export revenues were more than 20 times the 1976 figure of USD 7.8 billion (FAO 2020a). In addition to the above-mentioned factors, innovations in processing, storage, packaging, transport, and marketing helped stimulate seafood trade.

China is a major seafood-producing country. According to the statistics collected by FAO in 2018, worldwide seafood capture production reached 96.43 million tons, of which China accounted for 14.64 million (15.18\%); meanwhile, worldwide aquaculture fish production was 82.1 million tons, and China accounted for 47.56 million (57.93\%). Also, in 2018, China ranked first in the world in total seafood export value (USD 21.55 billion) and third in total import value (USD 11.92 billion) based on UN Comtrade Database. China's improved overall position in global trade is attributable to the "reform and opening up," beginning in the late 1970s. In 2001, China became a member of WTO, signaling its deeper integration into the world economy. WTO accession required changes in China's institutional structure and a host of new trade-related laws and regulations, resulting in improved transparency and stability in its business dealings (Fojtíková 2018).

Since 2006, China has formulated three national 5-year plans for the development of fisheries - namely, the 11th (2006-2010), 12th (2011-2015), and 13th (2016-2020) 5-year plans for national fishery development. These plans involved analyzing the opportunities and challenges faced at each stage and setting out detailed objectives and priorities for the phased development of aquaculture and fisheries. In 2013, President Xi introduced the Belt and Road Initiative, aiming to promote connectivity among the Asian, European, and African continents and facilitate policy coordination, unimpeded trade, and financial integration (NDRC 2015). Regarding fisheries, the initiative encouraged fishery enterprises to go abroad, undertake bilateral and multilateral fishery cooperation, and participate in international fishery associations. This provided development opportunities for the international trade of Chinese aquatic products. However, China's aquatic product exports also saw erratic fluctuations and unstable growth while facing challenges such as trade frictions, antidumping and antisubsidy investigations, and tariff barriers, including stringent sanitary and phytosanitary standards (SPS) and other technical barriers to trade (TBT). Against this background, studying the factors that affect fluctuations in China's aquatic product exports and analyzing the underlying reasons could help identify guidelines for the sustainable development of the foreign trade of aquatic products. Meanwhile, this research could also help China's import partners to better understand bilateral trade with China to facilitate improved policy and planning for aquatic product imports.

The rest of this paper is organized as follows. The "Literature review" section reviews the literature on the foreign trade of Chinese aquatic products as well as the related research methods. The "Overview of China's seafood export trade" section describes the current state of China's aquatic product export trade, including the trade scale, product structure, 
market distribution, and rejected cases. The "Data and method" section presents the constant market share (CMS) model used in this study. The "Results and discussion" section presents and discusses the results while the "Conclusion and policy suggestions" section concludes and offers policy suggestions.

\section{Literature review}

\section{China's seafood exports}

With ongoing economic globalization, in tandem with a higher awareness of the health benefits of seafood consumption, international trade in aquatic products has increased, attracting considerable research attention (Gephart and Pace 2015; Crona et al. 2015; Sabau and Muktadir Boksh 2017; Chen et al. 2018; Ping et al. 2018; Giusti et al. 2019; Geetha et al. 2020; Jin-Kai and Jian-Qiu 2020). With China becoming one of the world's major exporters of aquatic products, many studies have specifically focused on China's seafood exports.

Bo et al. (2017) used a gravity model to analyze the factors affecting China's aquatic product exports in Central and Eastern European countries. They found that the distance between China and the importing countries and EU membership were negatively correlated with the scale of China's aquatic product exports to those countries. Meanwhile, China's total output of aquatic products, the GDPs of the importing countries, the ratio of China's exchange rate with the importing countries, and WTO membership all showed positive correlations. Wen-Bo et al. (2017) noted that the market demand for tilapia, penaeid shrimp, Macrobrachium prawns, and catfish was important for stimulating production growth, both in China and abroad; although dependence on international markets was risky, export and trade were still important, especially as China aimed to become modernized. Further to this, meeting the high standards of the international market provided lessons that could help China meet its changing demand for farmed aquaculture products. Using a gravity model, Yang et al. (2020) investigated the determinants of China's seafood exports. They found that transportation costs and wealth level seemed to be much more important for products with higher perishability, while the impacts were insignificant on some other products (e.g., conserved mollusks and prepared crustaceans). Furthermore, most trade flows were driven by increased income but with highly varying degrees. Using CMS to investigate the factors affecting fluctuations in tilapia exports, Yun-Yun et al. (2020) found that Chinese tilapia products were oversupplied and had lost competitiveness; changing that situation would require transforming Chinese tilapia into a low-supply, high-quality, high-price product. Deng-Jun et al. (2014) found a complementary relationship between seafood exports from China and developed countries, where developing countries tended to specialize in labor-intensive products and exported them to capital-abundant countries; this resulted in a high degree of overlap between seafood exports from China and other developing countries in terms of seafood export mix and export prices. Collecting 4047 cases of rejection from February 2011 to July 2017, Xiao-Wei et al. (2018) analyzed the reasons why Chinese food exports (including aquatic products) were rejected by the US Food and Drug Administration (FDA); they proposed that China should improve its food safety laws, regulations, and standards to better match with its trading partners. Jing-Jing (2015) 
noted that the SPS measures of developed countries constrained China's aquatic product exports; thus, improving standards and quality and safety management would support the long-term growth of China's aquatic product exports.

\section{Constant market share model}

Constant market share (CMS) was first proposed by Tyszynski (1951). Since then, Milana (1988), Jepma (1989), and Ahmadi-Esfahani (2006), among others, have revised, improved, and expanded the model. CMS is now widely used to study international trade fluctuations and industrial competitiveness and to provide empirical evidence for policy recommendations (Widodo 2010; Fligenspan et al. 2015; Jinzhuo et al. 2016; Varalakshmi and Devatkal 2017; Aguiar et al. 2017; Capobianco-Uriarte et al. 2017; Zheng-Xin et al. 2017; Xu-Ping et al. 2018; Yun-jie and Jie 2018; Yan et al. 2020; Yun-Yun et al. 2020). Widodo (2010), for example, used CMS to analyze the dynamic markets of the EU, North American Free Trade Agreement (NAFTA), Northeast Asia, and ASEAN countries for the period 1980-2006. Zheng-Xin et al. (2017), meanwhile, used a CMS model to decompose the factors affecting export fluctuations in China's new energy industries; they found that the import demand of the international market for China's new energy industry dominated fluctuations in exports. Capobianco-Uriarte et al. (2017) used CMS to analyze Spain's competitiveness in the European tomato market. Also, using a CMS model, Xu-Ping et al. (2018) investigated the factors affecting China's forest product exports; they found that the competitive effect had the biggest influence on export growth, followed by market-size effects, with the effects of market distribution and product structure both being small. Analyzing the factors affecting China's exports of agricultural products to Pakistan, Yun-jie and Jie (2018) found that export growth was affected by both structural and competitive effects. Meanwhile, Yan et al. (2020) analyzed the dynamics of Australia's liquefied natural gas export performance using CMS and UN Comtrade data for four subperiods spanning 1989-2017.

Our review revealed that there are few English-language studies of the factors affecting China's trade in aquatic products. In general, gravity models (Lin et al. 2020; Nasrullah et al. 2020; Zhihui et al. 2020; Natale et al. 2015) and CMS models are commonly used to study the determinants of export performance. Many variables can affect export volatility, including a trading partner's GDP, distance between countries, infrastructure, the macroeconomic environment, and financial market development; it is not easy to comprehensively and accurately account for all of them. CMS, however, is able to yield precise hypotheses and, thereby, indicates the direction for further research (Ahmadi-Esfahani 2006). It is a "macroscopic" framework, which constitutes an important supplement to the other empirical models, as well as a feasible method of analyzing and exploring the factors involved (Zheng-Xin et al. 2017). The present study aimed to fill gaps in the literature in the following ways: (1) We calculated the factors affecting fluctuations in China's aquatic product exports and their degree of contribution using a CMS model based on the UN Comtrade Database covering 2000-2018. (2) We further decomposed the factors and their contribution in terms of the destination market level and the subdivision of aquatic product level. (3) Based on the results, we made suggestions to support the development of China's seafood exports and to help China's major trading partners to better understand trade with China and adjust their import policies accordingly. 


\section{Overview of China's seafood export trade}

\section{Export trade scale}

China has seen the rapid development of its aquatic product exports in recent years. However, it also faces many challenges and has experienced unstable growth, which have affected its international market share and sustainable development.

Since joining the WTO in 2001, China's aquatic product export trade has developed rapidly. In 2000, the trade volume of China's aquatic product exports was USD \$3651.9 million. By 2004, it had reached \$6631.3, with an annual growth rate of $26.63 \%$. Since 2005, however, drug residues in aquatic products have posed an obstacle for Chinese exports. The illegal use of malachite green in aquatic products was first exposed in China in July 2005; subsequently, malachite green drug residues were found in Chinese aquatic products exported to Japan, the EU, and Hong Kong (Yuxiang and Zheng 2006). In the same year, the EU and Japan detected nitrofuran metabolite residues in Chinese fish product exports (Yuxiang and Zheng 2006). Then, in 2006, the USA and Canada both reported chloramphenicol, malachite green, nitrofuran, and other banned drugs in Chinese aquatic products, while Japan detected endosulfan in Chinese eel (Zengsheng and Zheng 2007). In 2007, some aquatic products exported by China were found to contain vibrio cholera and methanol (Zengsheng and Zheng 2007). Although China took measures to control drug residues in its aquatic products, these incidents contributed to a slowdown of China's aquatic product exports. The annual growth rate of exports started to decrease after 2005. In 2009, affected by the global financial crisis, the annual growth rate of China's aquatic product exports fell to $1.33 \%$. After 2009, however, as the world economy recovered, exports resumed their high-speed growth, and China's aquatic exports more than doubled, from \$10,222.5 in 2009 to \$20,867 million in 2014. Yet, with the various measures taken to rescue markets after the crisis, many governments faced serious fiscal deficits. A structural crisis in economic development began to emerge, and the global economy entered another recession in 2015. At that time, the annual growth rate of China's aquatic product exports changed from positive to negative and experienced another slowdown.

Regarding the global market share of Chinese aquatic product exports, during the periods of 2000-2006 and 2009-2012, China's market share showed rapid growth while during 2004-2009 and 2012-2018, China's market share fluctuated around 10.99\% and $15.28 \%$, respectively. Table 1 shows the details.

\section{Export trade structure}

In the Standard International Trade Classification (SITC) Rev. 3, code 03 refers to aquatic products; it is further classified into 034, 035, 036, and 037. Because of the differences between 0371 and 0372 , we divided China's aquatic products into five subdivisions: 034, 035, 036, 0371, and 0372. Table 2 shows the definitions of the different codes.

Figures 1 and 2 show changes in the trade volume of China's aquatic product subdivisions and their share in China's total aquatic product exports (SITC 03). Figure 1 shows a general growth trend in the export volume of all subdivisions of China's aquatic products. From 2000 to 2018, codes 034, 035, 036, 0371, and 0372 increased by $521 \%, 345 \%, 390 \%$, $293 \%$, and $911 \%$, respectively. 
Table 1 China's aquatic product export volume, annual growth rate, and global market share; data based on the UN Comtrade Database

\begin{tabular}{lccl}
\hline Year & $\begin{array}{l}\text { Aquatic product export vol- } \\
\text { ume (SITC 03; million USD) }\end{array}$ & Annual growth rate & $\begin{array}{l}\text { Market share of China's aquatic product } \\
\text { exports in global aquatic product export } \\
\text { volume }\end{array}$ \\
\hline 2000 & 3651.90 & & 7.30 \\
2001 & 3996.46 & 9.44 & 7.88 \\
2002 & 4480.13 & 12.10 & 8.61 \\
2003 & 5236.83 & 16.89 & 9.07 \\
2004 & 6631.30 & 26.63 & 10.24 \\
2005 & 7511.30 & 13.27 & 10.61 \\
2006 & 8949.36 & 19.15 & 11.44 \\
2007 & 9230.10 & 3.14 & 10.91 \\
2008 & $10,088.08$ & 9.30 & 10.96 \\
2009 & $10,222.52$ & 1.33 & 11.77 \\
2010 & $13,198.08$ & 29.11 & 13.13 \\
2011 & $16,969.05$ & 28.57 & 14.18 \\
2012 & $18,122.34$ & 6.80 & 15.16 \\
2013 & $19,433.09$ & 7.23 & 15.12 \\
2014 & $20,867.07$ & 7.38 & 15.34 \\
2015 & $19,569.32$ & -6.22 & 16.11 \\
2016 & $19,998.68$ & 2.19 & 15.31 \\
2017 & $19,889.35$ & -0.55 & 14.87 \\
2018 & $21,029.25$ & 5.73 & 15.07 \\
\hline & & & \\
\hline
\end{tabular}

Table 2 Aquatic product codes and definitions (from Standard International Trade Classification Rev. 3)

\begin{tabular}{|c|c|}
\hline Code & Definition \\
\hline SITC 03 & $\begin{array}{l}\text { Fish (not marine mammals), crustaceans, mollusks, and aquatic invertebrates, and preparations } \\
\text { thereof }\end{array}$ \\
\hline SITC 034 & Fish, fresh (live or dead), chilled, or frozen \\
\hline SITC 035 & $\begin{array}{l}\text { Fish, dried, salted, or in brine; smoked fish (whether or not cooked before or during the smok- } \\
\text { ing process); flours, meals, and pellets of fish; fit for human consumption }\end{array}$ \\
\hline SITC 036 & $\begin{array}{l}\text { Crustaceans, mollusks, and aquatic invertebrates, whether in a shell or not; fresh (live or dead), } \\
\text { chilled, frozen, dried, salted, or in brine; crustaceans, in shell, cooked by steaming or boiling } \\
\text { in water, whether or not chilled, frozen, dried, or salted }\end{array}$ \\
\hline SITC 037 & $\begin{array}{l}\text { Fish, crustaceans, mollusks, and other aquatic invertebrates; prepared or preserved; NES (not } \\
\text { elsewhere specified) }\end{array}$ \\
\hline SITC 0371 & Fish, prepared or preserved, NES; caviar and caviar substitutes prepared from fish eggs \\
\hline SITC 0372 & Crustaceans, mollusks, and other aquatic invertebrates, prepared or preserved; NES \\
\hline
\end{tabular}

Regarding the contributions of specific aquatic product subdivisions, in 2000, 034 accounted for $35.86 \%$ of the total export volume of China's aquatic products. By 2018, it had only grown to $38.67 \%$, despite a fivefold increase in export volume. The contributions made by 035,036 , and 0371 reduced from $3.02 \%, 23.02 \%$, and $25.57 \%$ in 2000 to $2.33 \%$, $19.57 \%$, and $17.43 \%$, respectively, in 2018. However, from 2000 to 2018, we can see the 


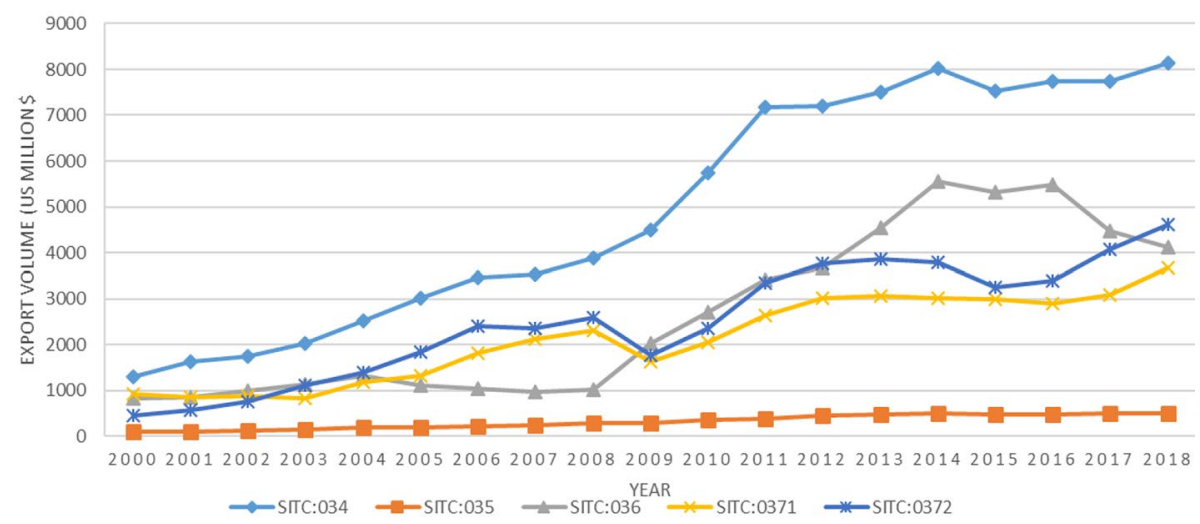

Fig. 1 Changes in the export volume of China's aquatic product subdivisions; data based on UN Comtrade Database

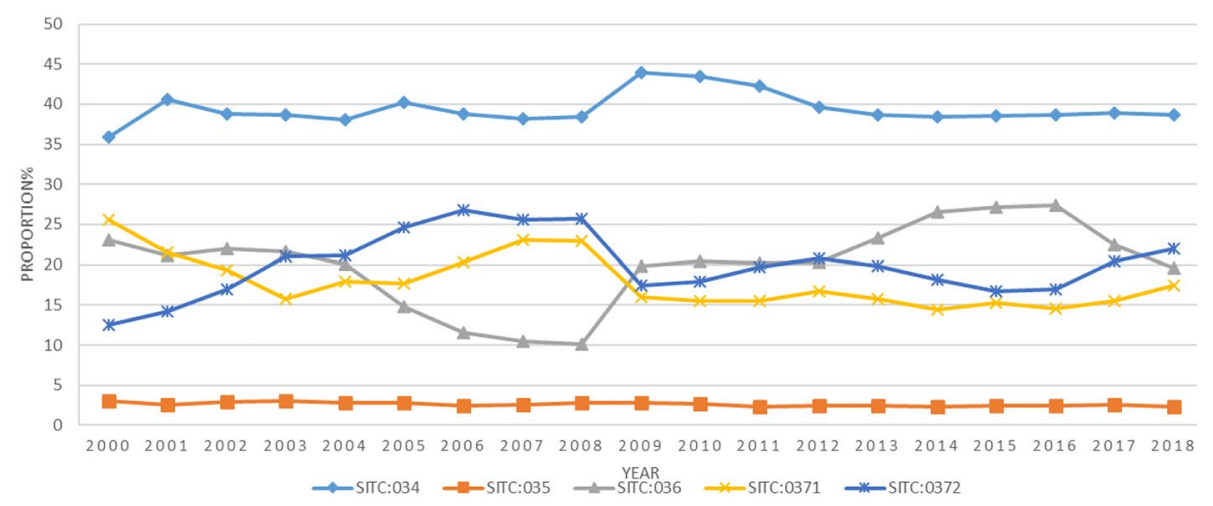

Fig. 2 Contributions made by aquatic product subdivisions in China's total aquatic product export volume; data based on UN Comtrade Database

rapid development of 0372. Its share in China's total aquatic product exports increased from 12.53 to $22 \%$, reflecting improvements in China's ability to process crustaceans, mollusks, and other aquatic invertebrates.

\section{Market distribution}

Here, to provide a better understanding of China's major export markets for aquatic products, we first list the top 10 regions/partners in China's aquatic product export trade. Then, given that ASEAN and the EU are among the world's largest regional economic organizations, and both have close economic relations with China, we also figured out the contributions of ASEAN and the EU to China's aquatic product exports.

Table 3 shows that Japan, the USA, and South Korea are the top export destinations for China's aquatic products. Together, the three countries accounted for $79.28 \%$ and $70.48 \%$ 


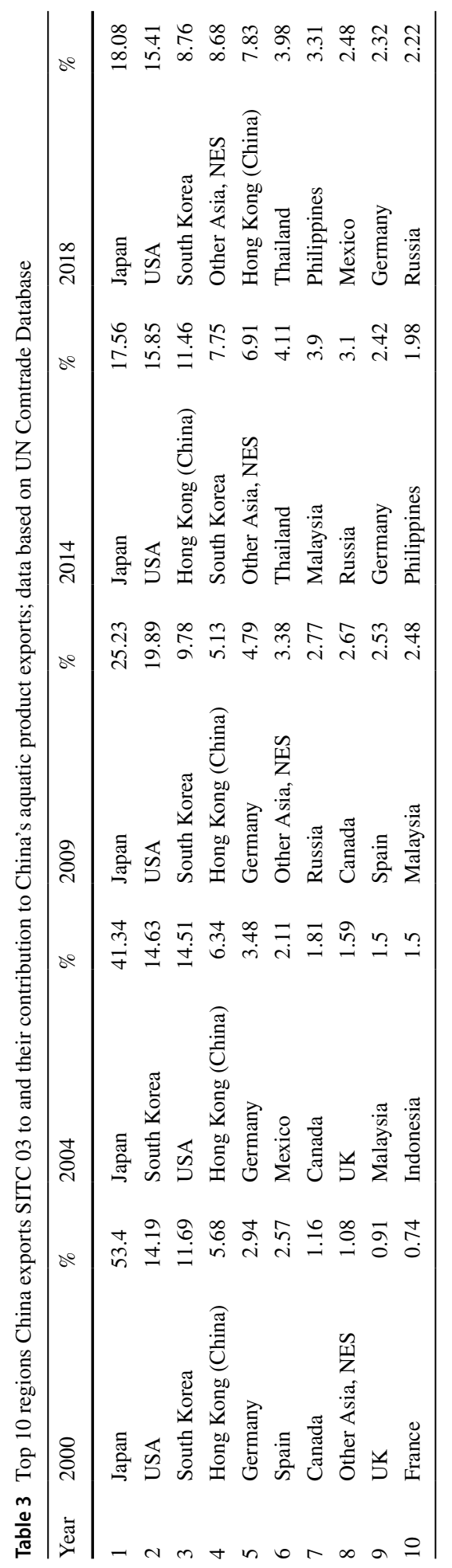


Table 4 Contribution of ASEAN and EU to China's aquatic product exports; based on UN Comtrade Database

\begin{tabular}{lccccc}
\hline Year (percentage) & $2000(\%)$ & $2004(\%)$ & $2009(\%)$ & $2014(\%)$ & $2018(\%)$ \\
\hline ASEAN & 1.23 & 5.09 & 6.84 & 12.63 & 12.42 \\
EU & 11.71 & 10.96 & 17.85 & 9.55 & 9.99 \\
\hline
\end{tabular}

The UK left the EU on January 31, 2020; since the export data in this study cover 2000-2018, EU data include the UK.

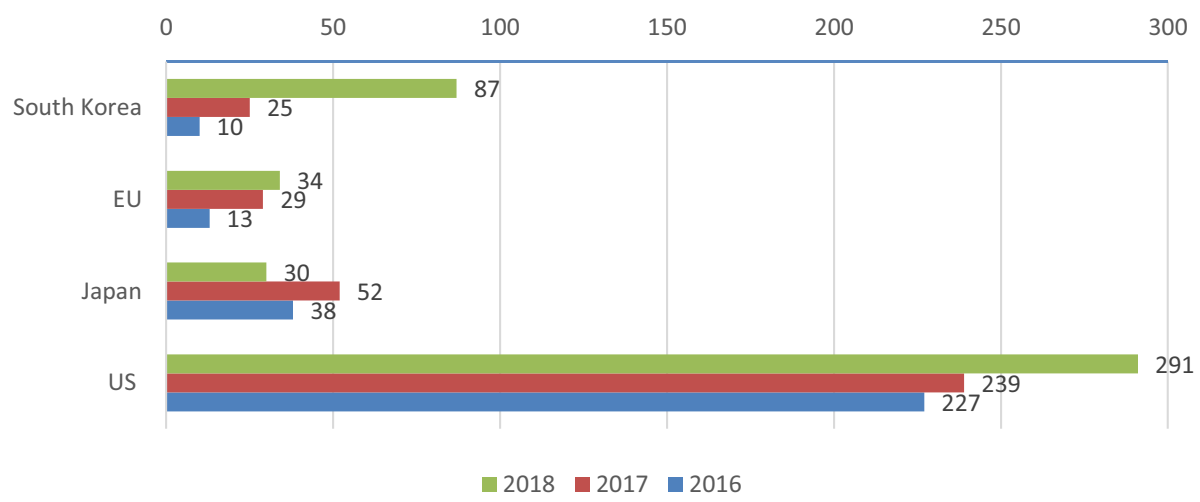

Fig. 3 Cases of Chinese aquatic product exports rejected by South Korea, the EU, Japan, and the USA in 2016, 2017, and 2018; data based on annual reports by Shenzhen Institute of Standards and Technology

of China's aquatic product exports (SITC 03) in 2000 and 2004, respectively. However, their combined proportion decreased to $42.25 \%$ in 2018.

The EU is another major import destination for China's aquatic products. Its proportion increased from 11.71 in 2000 to $17.85 \%$ in 2009 and then decreased to $9.99 \%$ in 2018. Table 4 shows the details.

Tables 3 and 4 show that Asian countries played an increasingly important role in China's exports. In 2000, ASEAN countries accounted for $1.23 \%$ of China's aquatic product exports, which increased to $12.42 \%$ in 2018. In addition, based on UN Comtrade statistics, in 2014 and 2018, "other Asian countries" (countries not listed by UN Comtrade) ranked fifth and fourth, respectively, among China's top five export destination markets.

Generally speaking, the export markets for Chinese aquatic products began to show a diversified trend. Table 3 gives details on the distributions of the top 10 regions for China's aquatic product exports in 2000, 2004, 2009, 2014, and 2018.

\section{Rejected cases of aquatic product exports}

China's aquatic product exports have faced many difficulties, among which export rejection has posed the most serious barrier to sustainable trade. Due to data limitations, only certain refusal cases are presented.

Figure 3 shows cases of Chinese aquatic product exports being rejected by the FDA; the Ministry of Health, Labor, and Welfare of Japan; the Rapid Alert System for Food and Feed of 
the EU; and the Ministry of Food and Drug Safety of South Korea in 2016, 2017, and 2018. The FDA rejected the largest number of products.

Figure 4 shows the number of refusals in 2018 and the related reasons. The top three reasons were containing pesticide and veterinary drug residues, being unqualified in quality or sensory examination, and containing microorganisms, such as bacteria.

\section{Data and method}

\section{Method}

The export trade scale, product structure, market distribution, and refusal cases of Chinese aquatic products shown above present a picture of China's aquatic product exports since 2000 and the possible reasons for fluctuations. However, descriptions based on UN Comtrade data and China Fisheries Yearbooks cannot provide deep insight into the reasons for changes in China's aquatic product exports. For this reason, this study introduced a CMS model for further analysis.

The CMS model assumes that a country's share in the world market should remain unchanged over time if the competitiveness of products remains constant. Therefore, changes in a country's exports may be attributable to changes in product competitiveness, resulting in changes in market share. Such changes might also be the result of changes in the commodity structure of the exporter or importer, or the interaction between the two. In terms of commodity structure, the model can help to understand whether a country's exports are concentrated in products with more significant demand growth. Meanwhile, in terms of market structure, CMS can help to determine whether a country's exports are concentrated in countries or regions with the fastest growth in demand. It can also analyze the factors that affect export trade volume under the different conditions of a constant market and constant product. Thus, it is possible to decompose the factors that affect a country's export trade volatility and quantify each factor's contribution to that country's export trade performance, aiming to understand the causes of and impediments to the growth of intercountry trade.

The basic form (first level) of the extended CMS model used in this study is as follows:

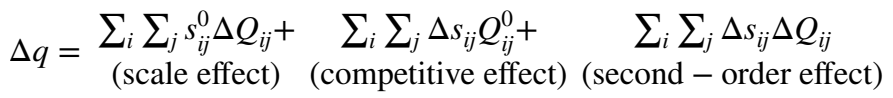

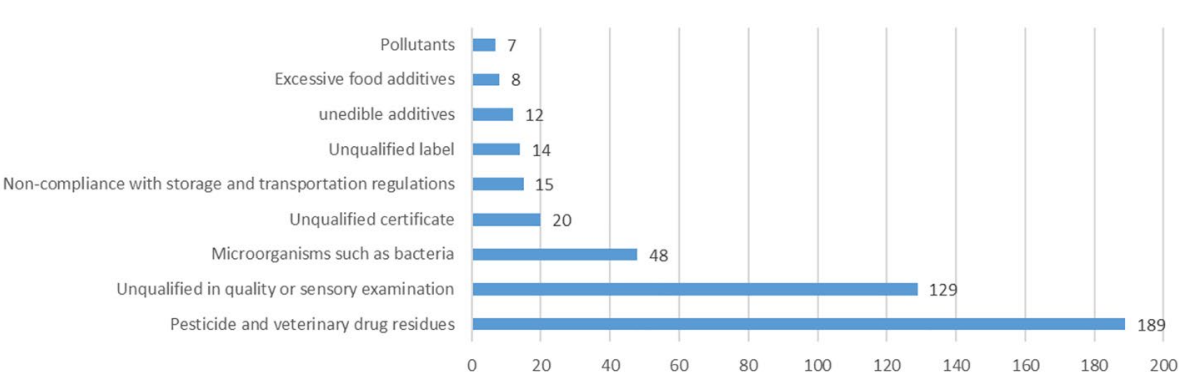

Fig. 4 Number of rejections and the reasons in 2018; data based on annual reports by Shenzhen Institute of Standards and Technology 
Then, the scale, competitive, and second-order effects are further decomposed as follows:

$$
\begin{aligned}
& \underset{\text { (scale-aggregate growth effect) }}{s^{0} \Delta \mathrm{Q}}+\underset{\text { (scale market effect) }}{\left.\sum_{i} \sum_{j} s_{i j}^{0} \Delta Q_{i j}-\sum_{i} s_{i}^{0} \Delta Q_{i}\right)}+\underset{\text { (scale product effect) }}{\left.\sum_{i} \sum_{j} s_{i j}^{0} \Delta Q_{i j}-\sum_{j} s_{j}^{0} \Delta Q_{j}\right) ;} \\
& {\left[\left(\sum_{i} s_{i}^{0} \Delta Q_{i}-s^{0} \Delta \mathrm{Q}\right)-\left(\sum_{i} \sum_{j} s_{i j}^{0} \Delta Q_{i j}-\sum_{j} s_{j}^{0} \Delta Q_{j}\right)\right]} \\
& \Delta q= \\
& \text { (scale interaction effect) }
\end{aligned}
$$

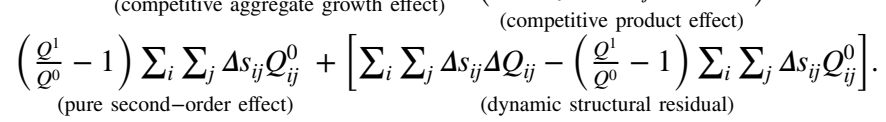

The meanings of the notations in Eqs. (1) and (2) and the interpretations of the firstand second-level decompositions are as follows: $\Delta q$ represents the change in the export value of a country's aquatic products within a time span; 0 and 1 are superscripts that denote the initial year and the final year of the comparison, respectively; $i$ and $j$ are subscripts that indicate a certain product and target market; $Q$ refers to the total import value of aquatic products in the world market; $Q_{i j}$ is the total import value of product $i$ in target market $j$; $S$ denotes the proportion of China's total aquatic product exports in the total worldwide import of aquatic products; and $S_{i j}$ is the proportion of China's aquatic product export $i$ in the overall imported aquatic product $i$ of target market $j$ in the world market.

The meanings of the various effects are as follows: The scale effect $\left(\sum_{i} \sum_{j} s_{i j}^{0} \Delta Q_{i j}\right)$ refers to changes in export value due to changes in the structure and scale of the importing market's demand, under the assumption that the exporting country's market shares are still constant in the importing markets. This can be further decomposed into four effects. The scale-aggregate growth effect $\left(s^{0} \Delta Q\right)$ denotes changes in the export value of the exporting country due to changes in the whole market's import scale. The scale market effect $\left(\sum_{i} \sum_{j} s_{i j}^{0} \Delta Q_{i j}-\sum_{i} s_{i}^{0} \Delta Q_{i}\right)$ denotes changes in export value due to changes in the exporting country's market share. The positive value represents the country's exports to a market where demand is growing rapidly, and the negative value denotes the country's exports to a market where demand is growing slowly. The scale product effect $\left(\sum_{i} \sum_{j} s_{i j}^{0} \Delta Q_{i j}-\sum_{j} s_{j}^{0} \Delta Q_{j}\right)$ indicates changes in export value due to changes in the proportions of different products; this reflects the degree of compatibility between China's aquatic product exports and the products imported in the target market with faster growth. A positive value means that products exported by the country are products with a growing demand in the import market while a negative value reflects means the exported products are products with slow growth in market demand. The scale interaction effect $\left[\left(\sum_{i} s_{i}^{0} \Delta Q_{i}-s^{0} \Delta Q\right)-\left(\sum_{i} \sum_{j} s_{i j}^{0} \Delta Q_{i j}-\sum_{j} s_{j}^{0} \Delta Q_{j}\right)\right]$ denotes changes in export value due to the interaction between product structure and market effect.

The competitive effect $\left(\sum_{i} \sum_{j} \Delta s_{i j} Q_{i j}^{0}\right)$ refers to changes in export value due to changes in the exporting country's competitiveness, under the assumption that the structure and size of the importing markets remain unchanged. This reflects the exporting country's ability to maintain its market share in the importing markets. This can be further decomposed into two effects. The competitive aggregate growth effect $\left(\Delta s Q^{0}\right)$ indicates changes in export value due to changes in the exporting country's total competitiveness; this is reflected by the country's export share under the assumption that the demand of importing markets remains unchanged. The competitive product effect 
$\left(\sum_{i} \sum_{j} \Delta s_{i j} Q_{i j}^{0}-\Delta s Q^{0}\right)$ refers to changes in export value due to changes in the exporting country's market share with various commodities in the importing target markets.

The second-order effect $\left(\sum_{i} \sum_{j} \Delta s_{i j} \Delta Q_{i j}\right)$ refers to changes in export value due to interaction between changes in the exporting country's competitiveness and changes in the structure and scale of the importing market's demand. This can be further decomposed into two effects. The pure second-order effect $\left[\left(\frac{Q^{1}}{Q^{0}}-1\right) \sum_{i} \sum_{j} \Delta s_{i j} Q_{i j}^{0}\right]$ denotes changes in export value due to the interaction between a country's export competitiveness (export market share) and changes in the importing market's demand. If the value is greater than 0 , the change in the export competitiveness of a country's aquatic products is consistent with the change in the scale of the importing markets and vice versa. The dynamic structural residual $\left[\sum_{i} \sum_{j} \Delta s_{i j} \Delta Q_{i j}-\left(\frac{Q^{1}}{Q^{0}}-1\right) \sum_{i} \sum_{j} \Delta s_{i j} Q_{i j}^{0}\right]$ indicates changes in exports due to the interaction between the exporting country's competitiveness (export market share) and changes in the structure of the importing market's demand.

\section{Data sources and stage divisions}

All of the data for aquatic product exports from 2000 to 2018 came from the UN Comtrade Database. We put the data into the CMS model for calculation and analysis. As mentioned earlier, in SITC Rev. 3, aquatic products belong to code 03, which is divided into four parts (034, 035, 036, and 037; see Table 2). Because of differences between codes 0371 and 0372, we divided aquatic products into five parts $(034,035,036,0371,0372)$. Regarding destination markets, we selected the USA, Japan, South Korea, ASEAN countries, and the EU since they are the major importers of Chinese aquatic products.

The study period was divided into five stages based on the analysis in the "Export trade scale" section. The first stage is 2000-2004, when China's aquatic product exports grew quickly after WTO accession. The second stage is 2004-2008, during which the annual growth rate was unstable. The third stage covers 2008-2009, the period of the global financial crisis. The fourth stage is 2009-2014, when aquatic product exports rose quickly due to recovery from the crisis. The last stage is 2014-2018.

\section{Results and discussion}

\section{First-level decomposition of the CMS model}

Table 5 shows that the first stage (2000-2004) saw the rapid development of China's aquatic product exports, which increased quickly by USD 2979.4 million. Scale effect, competitive effect, and second-order effect all promoted the growth of aquatic product exports, with contributions of $30.27 \%, 53.87 \%$, and $15.86 \%$ respectively. After China's accession to the WTO in 2001, it increased investment in aquaculture and fisheries and set up development funds to renovate fish/shrimp breeding ponds and purchase instruments and equipment to promote fishery development. China also organized research projects on fisheries at that time and enacted laws and regulations to promote exports. With China's rich fishery resources and low labor costs, at this stage, the competitive effect dominated increases in China's aquatic product exports, followed by scale and second-order effects.

During the second stage (2004-2008), China's aquatic product exports continued to show a growing trend, and three effects played a positive role. Now, however, the scale 


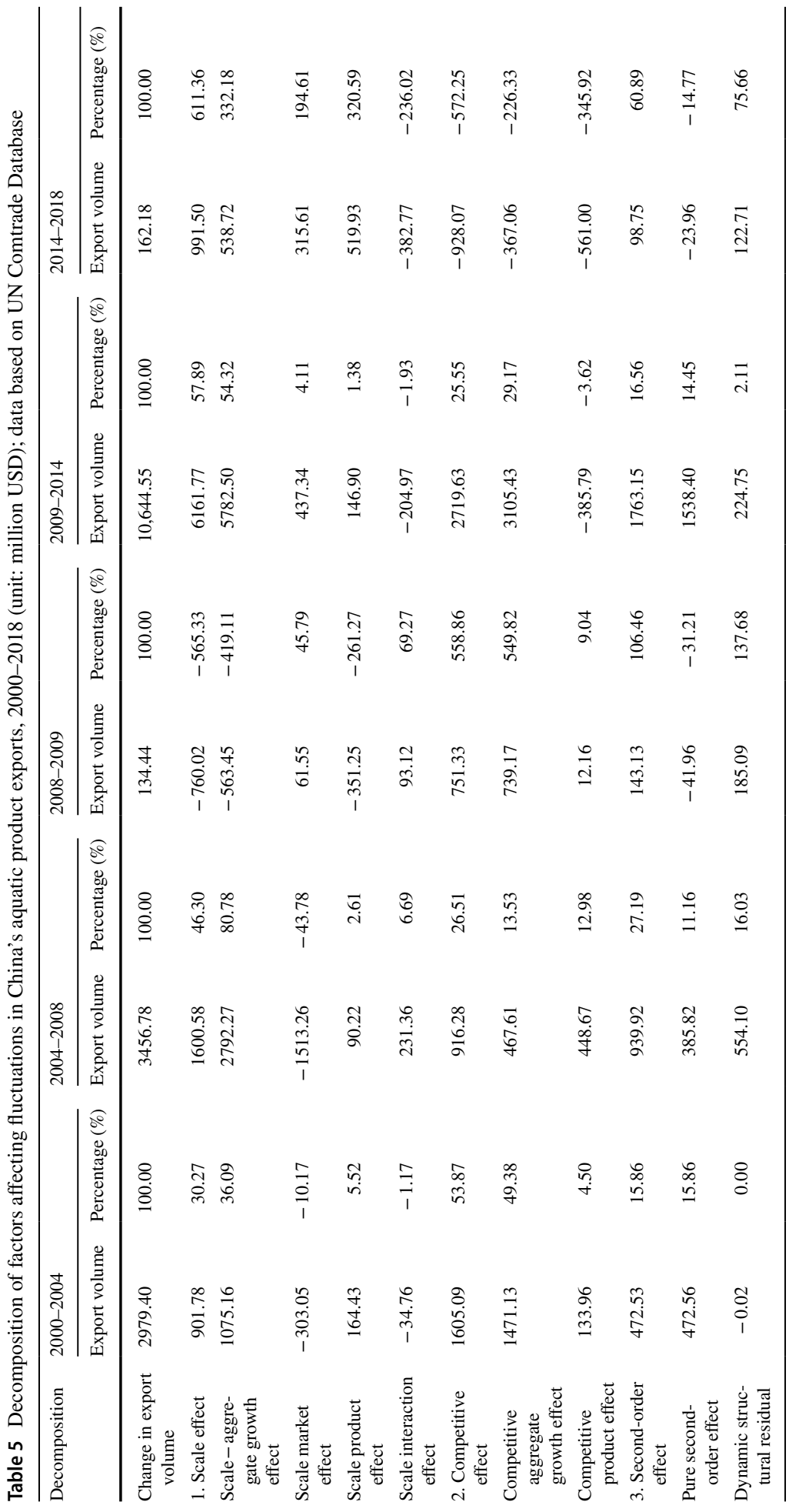


effect had become the most important contributor. The contribution of the competitive effect decreased from $53.87 \%$ in the previous period to $26.51 \%$, becoming the least important factor. High antidumping duties imposed by the USA on Chinese shrimp in 2004, as well as a series of aquatic product safety incidents, dramatically reduced the competitiveness of China's aquatic products in the international market.

The global financial crisis occurred during the third stage (2008-2009). It spread to almost all areas of the global economy, caused a great recession, increased unemployment rates, and negatively affected international trade. During this period, China's aquatic product export trade value increased by only $\$ 134.44$ million. Compared to the previous two stages, for the first time, the scale effect inhibited rather than enhanced China's aquatic product exports, meaning the entire global demand for aquatic products was greatly reduced. The scale effect decreased the export volume of the industry by $\$ 760.02$ million.

During the fourth stage (2009-2014), with the recovery of the global economy, the international trade of aquatic products entered a stage of rapid development. China's aquatic product exports increased by $\$ 10,644.55$ million, reaching their highest point. The scale effect turned positive again and became a major factor promoting China's export trade value, leading to an increase of $\$ 6161.77$ million, with a contribution of $57.89 \%$; this indicated rapid growth in the global import demand for aquatic products. The contributions of competitive and second-order effects were $25.55 \%$ and $16.56 \%$, respectively.

During the fifth stage (2014-2018), the growth of China's aquatic product exports was again blocked. As a result of various government measures taken in response to the 2008 crisis, the growth rate of the global economy slowed down again in 2015. Moreover, stricter SPS and TBT related to aquatic product imports, increased antisubsidy and antidumping investigations, and fiercer competition from other aquatic product producers all affected China's aquatic product exports to a certain extent. During this period, the export trade value of China's aquatic products only increased by $\$ 162.18$ million, almost equal to the amount during 2008-2009. The scale effect played the main role in promoting China's export value, with a contribution of $611.36 \%$, followed by the second-order effect. The competitive effect significantly inhibited exports, contributing $-572.25 \%$ to the change in China's trade value, indicating that China's aquatic product competitiveness was at a disadvantage.

\section{Second-level decomposition of the CMS model}

We further decomposed the scale effect. From 2000 to 2004, the scale-aggregate growth effect and scale product effect jointly increased China's aquatic product exports, contributing $36.09 \%$ and $5.52 \%$, respectively. The growing global demand for aquatic products promoted Chinese exports, and China's export product structure was consistent with the structure of global import demand. However, the contributions of scale market and scale interaction effects were negative, with values of $-10.17 \%$ and $-1.17 \%$, respectively.

From 2004 to 2008, the scale-aggregate growth, scale product, and scale interaction effects all played positive roles, enhancing China's aquatic product exports by $\$ 2792.27$, $\$ 90.22$, and $\$ 231.36$ million, respectively. Scale-aggregate growth effect was the most influential effect, contributing $80.78 \%$. However, the influence of the scale market effect decreased from -10.17 to $-43.78 \%$, indicating that China's export market distribution became less suited to global demand and needed adjustment.

During 2008-2009, with the spread of financial crisis, the global import demand for aquatic products declined sharply. Scale-aggregate growth and product effects changed 
from positive to negative. The continuous decline of the scale product effect indicated that China's aquatic product exports were not products with a growing demand in import markets. Although the scale market and interaction effects were positive, they contributed very little to an increase in exports.

During 2009-2014, following recovery from the crisis, global import demand for aquatic products grew substantially. The scale-aggregate growth effect became the most important contributor, increasing China's exports by $\$ 5782.5$ million and contributing $54.32 \%$. Scale market and scale product effects also played a positive role, indicating that China's product structure and market distribution were in line with global demand. At this stage, the scale interaction effect was negative but insignificant at $-1.93 \%$.

From 2014 to 2018, the scale-aggregate growth, scale market, and scale product effects continued to be positive, increasing China's exports by $\$ 538.72, \$ 315.61$, and $\$ 519.93$ million, respectively. The improvement of the scale market and scale product effects indicated that China's export market distribution and product structure both matched well with global import demand. At this stage, the contribution of the scale interaction effect was $-236.02 \%$, indicating that the interaction of product structure and market effect played a negative role.

Next, we further decomposed the competitive effect. From 2000 to 2004, the competitive aggregate growth effect had the greatest effect on China's aquatic product exports, increasing them by $\$ 1471.13$ million and contributing $49.38 \%$. This indicated the strong overall competitiveness of China's aquatic product exports. It continued to play positive but fluctuating role in promoting China's aquatic product exports during the three periods of 2004-2008, 2008-2009, and 2009-2014. Then, from 2014 to 2018, the competitive aggregate growth effect was negative, contributing $-226.33 \%$ and decreasing China's aquatic product exports by 367.06 million. Thus, China's share in global aquatic products was greatly reduced.

Regarding the competitive product effect, a positive value means a specific product's competitiveness, reflected by market share, has a favorable effect on the country's exports; a negative value indicates otherwise. During the periods of 2000-2004, 2004-2008, and 2008-2009, the contributions of the competitive product effect were positive at $4.5 \%$, $12.98 \%$, and $9.04 \%$, respectively, promoting China's aquatic product exports by $\$ 133.96$, $\$ 448.67$, and $\$ 12.16$ million, respectively. However, from 2009 to 2014, the competitive product effect turned negative and reduced China's aquatic product exports by $\$ 385.79$ million, with a contribution of $-3.62 \%$. Worse, it continued to drop from 2014 to 2018, indicating China's competitiveness with regard to specific products was declining.

We turn now to the second-order effect. During the periods of 2000-2004, 2004-2008, and 2009-2014, the contributions of the pure second-order effect were positive. This indicates that the change in the export competitiveness of China's aquatic products was consistent with changes in the scale of importing markets. However, from 2008 to 2009 and 2014 to 2018 , it was negative, decreasing China's aquatic product exports by $\$ 41.96$ and $\$ 23.96$ million, respectively.

In terms of the dynamic structural residual effect, from 2000 to 2004, it had nearly no effect on China's exports. However, after that, for the periods of 2004-2008, 2008-2009, 2009-2014, and 2014-2018, it promoted China's aquatic product exports by $\$ 554.1$, $\$ 185.09, \$ 224.75$, and $\$ 122.71$ million, respectively. Table 5 shows the details.

Overall, the competitiveness effect played a leading role in aquatic product exports during the early stage of China's WTO accession. Then, the scale effect became the dominant factor, meaning international market demand largely influenced the trade volume of Chinese aquatic product exports. Meanwhile, China's export market distribution and product 
structure became more adapted to the needs of international markets. However, the analyzed data indicated that China's competitiveness was on the decline.

\section{Decomposition of factors affecting fluctuations in China's aquatic product exports at the market level using CMS}

In this part, we consider the main destination markets for China's aquatic product exports, including the USA, Japan, South Korea, ASEAN countries, and the EU. A CMS model was used to decompose and analyze the reasons for changes in China's aquatic product exports to its partners.

Table 6 shows that, over time, the dominant factor influencing changes in the volume of China's aquatic product exports to the USA varied from the competitive effect to the scale effect. The second-order effect fluctuated between positive and negative, but, generally speaking, its contribution was insignificant. All of this indicates that the growth of China's aquatic product exports to the USA was mainly attributable to the increasing import demand of the USA while the competitiveness of Chinese aquatic products was declining in the USA. In 2018, the USA started imposing tariffs on various Chinese imports, and China imposed tariffs on US imports in response. This trade friction between the USA and China continued to escalate. There was a time lag between the release of the list of tariffed goods and the official implementation, which provided a buffer for aquatic product suppliers and distributors; this is why there was not a steep decline in aquatic product trade in 2018. In the long run, however, US-China trade friction had a significant negative effect on the aquatic product trade sector. Fish producers and processors that exported to the USA were at risk of closure. China's tariffs on US soybeans raised the cost of aquatic feed to a certain extent, squeezing the profit margins of enterprises. A failure to resolve US-China trade friction would mean a pessimistic outlook for US-China aquatic product trade.

Regarding the Japanese market, from 2000 to 2004, the competitive effect was the dominant factor, contributing $100.92 \%$, far greater than the $0.66 \%$ and $0.27 \%$ contributions of scale effect and second-order effect, respectively. After that time, the scale effect began to play a more important role in fluctuations in the value of aquatic product exports to Japan. Unlike the USA, during 2014-2018, the scale effect, competitive effect, and second-order effect all played positive roles, with contributions of $32.86 \%, 66.33 \%$, and $0.81 \%$, respectively. China's competitiveness in the Japanese market was the dominant factor enhancing China's aquatic product exports. After Japan's implementation of the Positive List of Pesticide Residues in Food, Chinese fishery exports to Japan started to face difficulties. Nevertheless, China and Japan have strengthened their cooperation in various fishery-related fields in recent years. After certain substandard fishery enterprises exporting to Japan were eliminated, Chinese fishery products started to maintain a degree of competitiveness in the Japanese market.

In the South Korean market, the contribution of scale effect remained positive and continued to increase, except during 2008-2009. This indicates that changes in exports of China's aquatic products to South Korea mainly depended on import demand. Meanwhile, the competitiveness effect showed a downward trend, implying that China had a weak ability to maintain its market share in South Korea. Moreover, after 2004, the second-order effect began to inhibit China's exports.

In the ASEAN market, the scale effect played the most important role in China's aquatic product exports, except during 2000-2004 and 2008-2009. Although there was an increasingly stable import demand in the ASEAN market for China's aquatic 
products, the competitive effect continuously declined. During 2014-2018, the scale effect increased China's aquatic product exports by $\$ 75.07$ million while the competitive and second-order effects decreased exports by $\$ 45.71$ and $\$ 1.30$ million, respectively. The establishment of the ASEAN-China Free Trade Area strengthened cooperation between the two parties. However, in terms of aquatic product exports, China is not very competitive in the ASEAN market. China is adjacent to ASEAN countries and has similar fishery resources. China therefore faces competition from large fishery countries within ASEAN. China should therefore consider ways to strengthen the complementarity of aquatic product trade with ASEAN countries according to their respective industrial structures.

Regarding the EU market, during the five stages, the contributions of the scale effect were far greater than the contributions of the competitive effect, except during 2004-2008. Regarding competitive effect, during 2009-2014 and 2014-2018, it decreased China's aquatic product exports by $\$ 275.84$ and $\$ 27.02$ million, contributing $-164.04 \%$ and $-18.43 \%$, respectively. This showed that China's competitiveness (market share) of aquatic product exports in the EU was declining. The EU's inspection and quarantine standards for fish imports are stringent and frequently updated. Although in recent years China has increased its aquatic product trade with certain EU countries, China's competitiveness in the EU market is generally low.

Apart from the main destination markets mentioned above, in other countries, during 2000-2004, 2008-2009, 2009-2014, and 2014-2018, the competitive effect played a dominant factor and helped increase China's exports. In recent years, China has participated in various trade-related negotiations, promoted the construction of free trade zones, fostered international fishery cooperation, pushed for a favorable environment for aquatic product trade, and expanded the aquatic product export markets. This is why China has been able to maintain competitiveness in a number of countries.

\section{Decomposition of factors affecting fluctuations in China's aquatic product exports at the product subdivision level using CMS}

Here, we account for the subdivision of aquatic products (SITC 03), including 034, 035, 036, 0371, and 0372. In this case, the CMS model was not needed to consider market distribution.

\section{SITC 034}

As shown in Table 7, except for 2008-2009 (the global financial crisis), in all other stages, the scale effect associated with 034 was positive and played a dominant role in promoting its export value for China. This means it was global demand that helped increase China's export volume of 034.

Overall, however, the competitive effect associated with 034 showed a declining trend, except during 2008-2009. From 2014 to 2018, its contribution plunged to $-677.7 \%$, indicating that China's competitiveness in 034 was declining.

Although the second-order effect fluctuated between positive and negative, during the whole period, it had the least effect on China's exports of 034. 


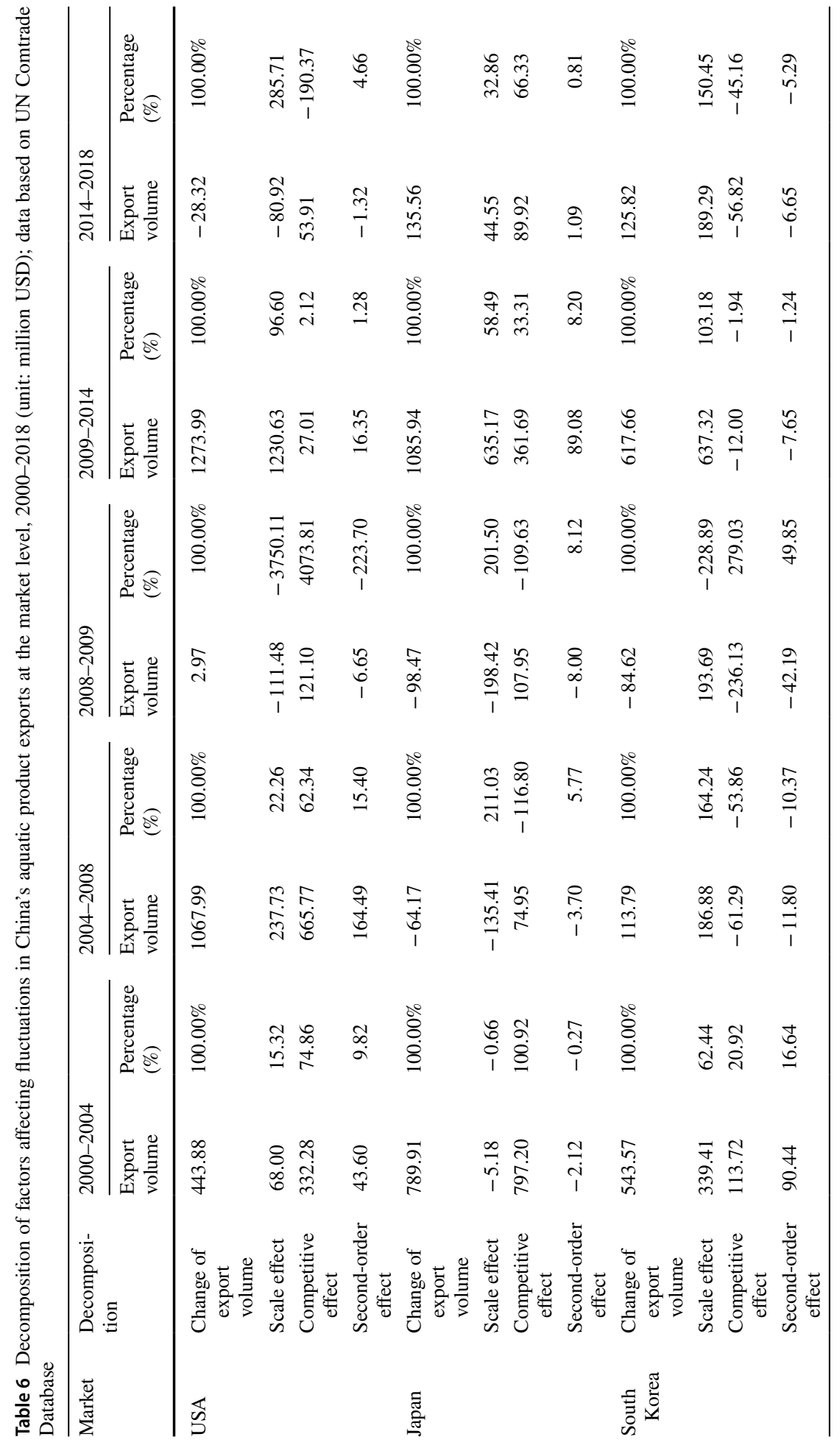




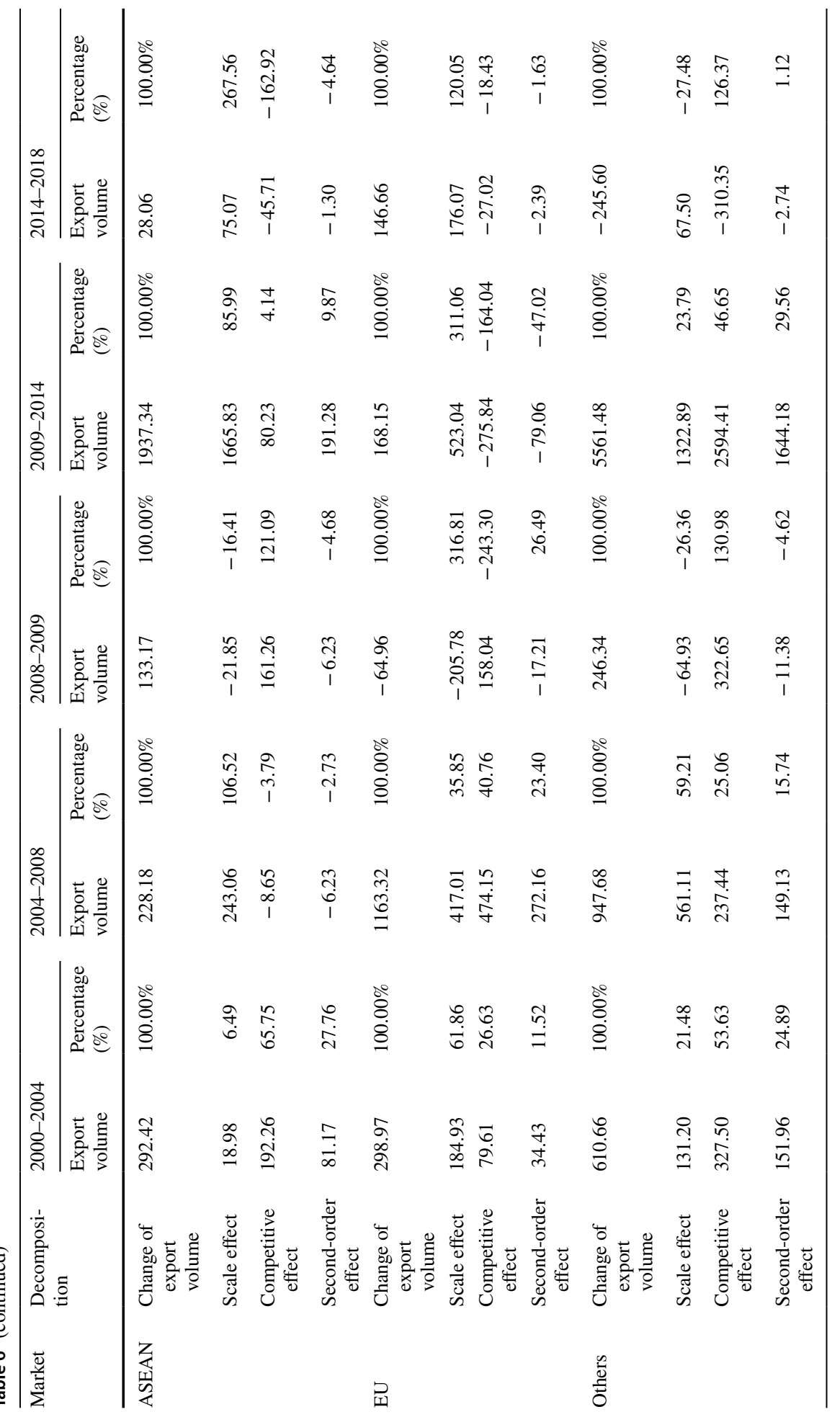




\section{SITC 035}

As for 035, during 2000-2004, the scale and competitive effects played nearly equal roles in increasing China's exports. Then, during 2004-2008 and 2009-2014, the scale, competitive, and second-order effects continued to jointly promote China's exports of 035 , with scale effect being dominant. Then, during 2014-2018, China's exports of 035 were reduced by $\$ 4.6$ million, and the competitiveness effect was the dominant factor reducing exports by $\$ 36.80$ million. At this stage, the scale effect increased China's exports of 035 by $\$ 34.78$ million. This means China's competitiveness in 035 needed improvement.

During all of the periods, the second-order effect contributed the least contribution to fluctuations in 035 exports. During 2000-2004, 2004-2008, and 2009-2014, the secondorder effect increased China's exports of 035, while in 2008-2009 and 2014-2018, it decreased China's exports.

\section{SITC 036}

During 2000-2009, fluctuations in exports of 036 were mainly attributable to the competitive effect. During 2000-2004 and 2008-2009, the competitive effect promoted China's exports of 036. However, during 2004-2008, the competitive effect inhibited China's exports. Then, scale effect began to play a dominant role. During 2009-2014, scale, competitive, and second-order effects increased China's exports of 036 by $\$ 1650.46,1030.80$, and $\$ 837.95$ million, contributing $46.90 \%, 29.29 \%$, and $23.81 \%$, respectively. However, from 2014 to 2018, China's exports of 036 dropped sharply. The scale effect and competitive effect decreased 036 exports by $\$ 964.27$ and $\$ 567.71$ million, respectively. This indicated that the global demand for 036 and China's market share of 036 both decreased significantly.

\section{SITC 0371}

During 2000-2004, only scale effect was positive, indicating that global demand was the main reason for China's export increase of 0371. Then, during 2004-2008, 2009-2014, and 2014-2018, China's competitiveness in 0371 steadily increased. From 2014 to 2018 , competitive, scale, and second-order effects all helped promote China's increase in 0371 exports. This time, however, the contribution of the competitive effect was $54.14 \%$, followed by scale effect and second-order effect. This reflected the development and improvement of China's processing technology for aquatic product 0371 .

The contribution of the second-order effect associated with 0371 helped increase China's exports of 0371, except during 2000-2004.

\section{SITC 0372}

During 2000-2004 and 2004-2008, all three effects promoted China's increases in 0372 exports, with competitive and scale effects alternately playing the leading role. During 2009-2014 and 2014-2018, the scale effect associated with 0372 was positive, representing a steady contribution. This means international import demand for 0372 was the major and stable effect increasing China's exports of 0372 from 2009 to 2018. Meanwhile, the competitive effect was improving with regard to 0372. From 2014 to 2018, its contribution 
grew to $41.31 \%$, compared to $29.72 \%$ during $2009-2014$, indicating that China's processing technology for 0371 was improving, and its market share was increasing.

During the whole period, the second-order effect continued to improve China's exports of 0372 , although its contribution fluctuated. This indicates that the interaction between changes in China's competitiveness and changes in the structure and scale of import demand was good for 0372 exports.

Generally speaking, global demand dominated the changes in China's exports of 034, 035, and 036. Moreover, we can see improved competitiveness with regard to 0371 and 0372 in global markets.

\section{Conclusion and policy suggestions}

\section{Conclusion}

China's aquatic product exports have grown rapidly over the past 20 years, with the volume of export trade nearly sextupling and the market share doubling. Using an extended CMS model, we decomposed the factors affecting export fluctuations in China's aquatic products. Generally speaking, the empirical results showed that changes in the international import demand for aquatic products were the most important factor affecting China's aquatic product exports. During 2004-2008, 2009-2014, and 2014-2018, the scale-aggregate growth effect was the most significant factor promoting China's aquatic product exports, with contribution rates of $80.78 \%, 54.32 \%$, and $332.18 \%$, respectively. Meanwhile, after 2009, the scale market and scale product effects both increased China's aquatic product exports. This indicates that China's export structure for aquatic products and its market distribution were becoming increasingly consistent with global market demand. Moreover, the competitive effect, including the competitive aggregate growth effect and competitive product effect, was declining. Therefore, areas China should focus on include improving the quality of aquatic products, meeting importing countries' SPS norms, and maintaining aquatic product market share and competitiveness.

As for market destinations, China's aquatic product market distribution showed a diversified trend. In 2000, Japan occupied 53.4\% of China's total export volume for aquatic products; by 2018, it was reduced to $18.08 \%$. The proportion of seafood exports to the USA, South Korea, and the EU also declined from 2009 to 2018. At the same time, the share of exports to other Asian countries increased. That said, Japan, the USA, and South Korea remain the top three importers of Chinese aquatic products. In this regard, China needs to consider how to further diversify and optimize its export destination markets and reduce risks. The results also indicated that scale effect showed a growing trend while the competitive effect had a declining trend in the USA, South Korea, ASEAN countries, and the EU. This suggests that the rapid growth of China's seafood exports was mainly attributable to growing global demand for aquatic products rather than improved competitiveness. As people become increasingly concerned about the safety and quality of aquatic products, the inspection and quarantine requirements set by many seafood-importing countries are becoming more stringent. How to meet such requirements and improve its export competitiveness and market share poses a major challenge for China.

Regarding the subdivision of aquatic products, China's aquatic products were mainly concentrated on labor- and resource-intensive types. After 2009, scale effect was the most important factor affecting China's exports of 034 and 036. Since 034 and 036 are not 


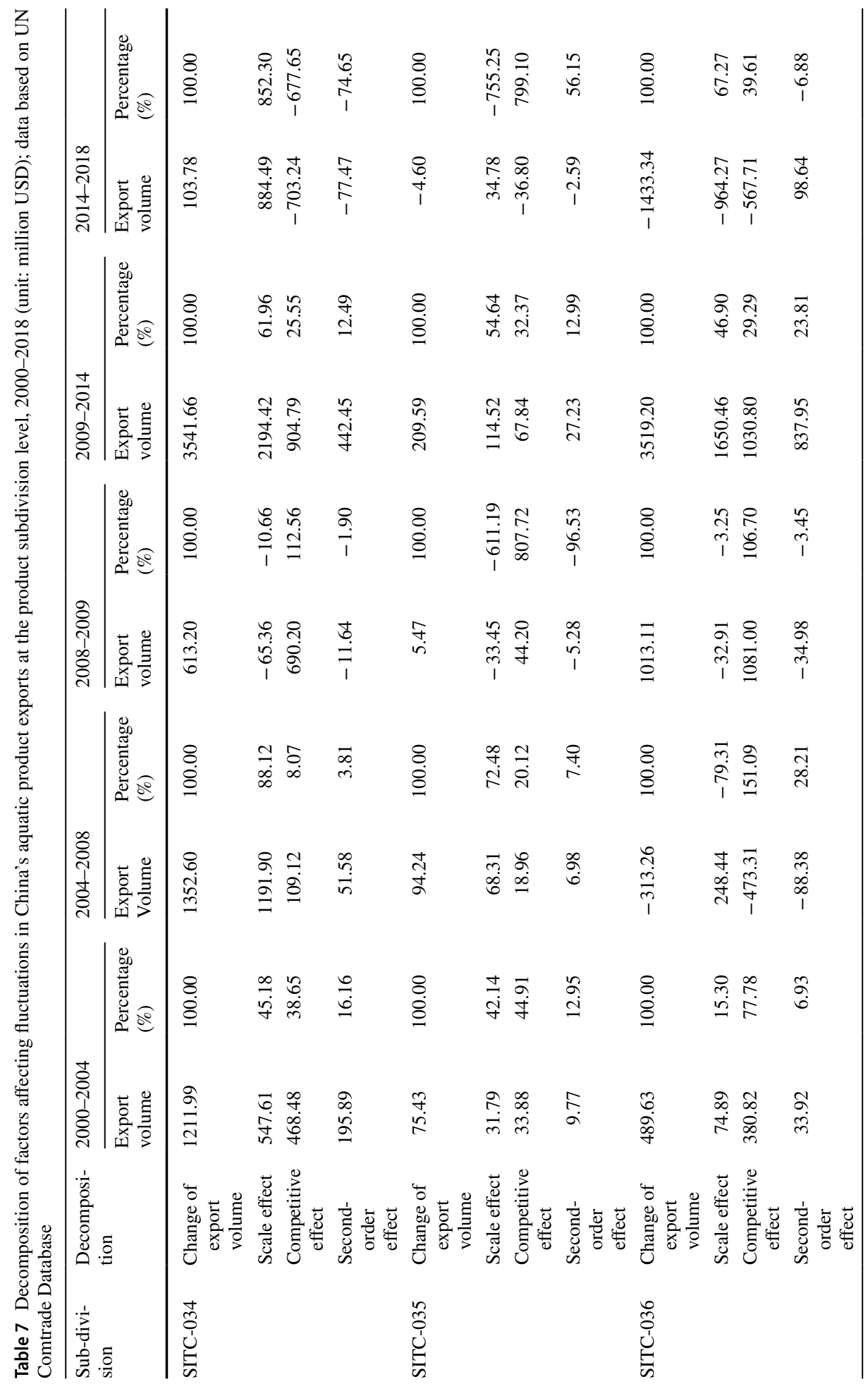




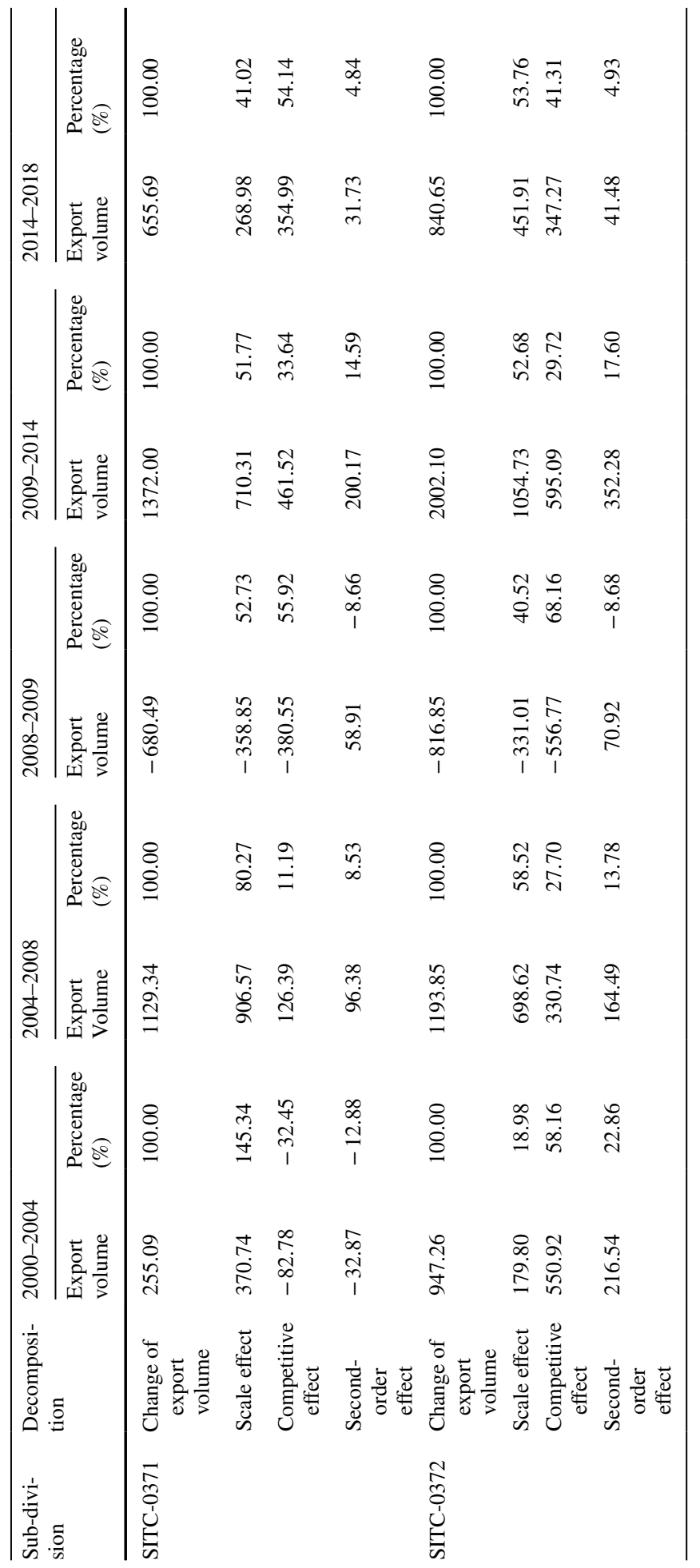


high-value-added aquatic products, in recent years, their market share has been challenged by competition from newly emerging Asian seafood exporters. However, the competitive effects of 0371 and 0372 showed growth, partly because of improvements in China's processing technologies in recent years. In more developed economies, fish processing has diversified into high-value-added products; likewise, in many developing countries, fish processing has been evolving from traditional methods to more advanced value-adding processes, depending on commodity and market value (FAO 2020a). Processed aquatic products therefore show some promising prospects. Yet, China still has a long way to go in terms of improving processing technologies and optimizing the aquatic product structure.

\section{Policy suggestions}

Maintaining China's aquatic product export trade lies not only in adjusting the product structure and market distribution to meet global import demands and improving product competitiveness but also in ensuring sustainable fishery and aquaculture. Therefore, the recommendations that follow are put forward.

(1) Sustainable fishery production is the basis for sustainable fish-export trade. It is therefore necessary to strengthen legal instruments to maintain the fishery ecosystem and establish an early warning mechanism for environmental pollution. It is also important to develop stock assessment methods and accurate data collection techniques to monitor the status of stocks and assess potential sustainability.

(2) Seafood company operators should be encouraged to adopt good practices, such as good hygiene and manufacturing practices. They also need to use a hazard analysis and critical control point system to assess whether their performance objectives are being achieved and whether their control measures are effective. Such measures can help guarantee the quality and safety of aquatic products and enhance international competitiveness.

(3) It is suggested that related departments should increase science and technology investment, strengthen R\&D on genetic breeding and disease prevention, and improve equipment and technology for fishing, breeding, and processing. Seafood enterprises should be encouraged to strengthen cooperation with universities and scientific research institutions at home and abroad. Using scientific and technological means, the industry can reduce production costs, improve quality, increase added value, and enhance international competitiveness.

(4) China should actively respond to technical barriers to trade (TBT). Drawing on the experiences of developed countries, China can build standardized systems for aquatic product quality and safety; further revise standards; strengthen the quality supervision of production, processing, and transportation; and participate in the formulation of industry standards. In the short term, TBT has had a negative effect on China's exports, but in the long run, it can help improve China's quality management system for seafood, thereby promoting industry development and connecting with international practice.

(5) It is important to increase research on the import needs, preferences, and requirements of major seafood-importing countries and partners. The structure of China's aquatic product exports should be adjusted to obtain the complementary advantages of import and export trade and maintain market share in these traditional markets. At the same time, enterprises should be guided to participate in or hold exhibitions, fairs, and promotional meetings to publicize China's aquatic products. This can help enhance the popularity of China's aquatic products and open up new markets. 
(6) China itself is a large importer of aquatic products. It is suggested to strengthen research on domestic fish consumption needs and preferences and encourage fish-selling enterprises to implement innovations in consumption patterns, distribution methods, and marketing methods to expand domestic demand and reduce dependence on global market demand.

(7) It is necessary for China's related departments to strengthen its exchange with other countries' fishery departments and set up a consultation mechanism. This could provide a platform for both departments to consult on issues related to seafood-trade disputes, ecosystem protection, and sustainable development.

(8) At the local level, it is suggested to give full play to the role of industry associations and encourage private fishery associations to establish federations with relevant foreign fishery NGOs to deepen their understanding of local fishing conditions and people's needs through exchange and cooperation. This could contribute to the smooth implementation of cooperative projects and bilateral trade.

Today, sustainable development goals have been agreed upon by 194 UN member states to guide development policies and initiatives in the coming years (Hambrey 2017). Maintaining the sustainable development of fishery production is one of the goals of China's national 5-year plan. However, the external international environment impacts the sustainable development of aquatic product exports. The recent escalation of trade tensions between China and the USA created uncertainty in the global fish market, and a number of heavily traded fish items were included on both countries' lists of tariffs; this has been the primary driver of a growth slowdown, not only in China and the USA but also globally. (FAO 2020a). Meanwhile, COVID-19 has also significantly affected international seafood trade. Measures to contain COVID-19 have affected the seafood supply chain, from fishing and aquaculture production, to processing, transport, and wholesale and retail marketing (FAO 2020b). In the face of an external environment characterized by a global economic downturn and a shrinking international market, President Xi proposed future development suggestions at a symposium for entrepreneurs held in July 2020. That is "we need to pool resources and concentrate on managing the country's affairs well, and give full play to the advantage of a huge domestic market, so that a new development pattern will gradually be created whereby domestic and foreign markets can boost each other, with the domestic market as the mainstay" (Jin-Ping 2020). It is clear that not only China but also the entire world has a long way to go to maintain sustainable international seafood trade.

Funding This research was supported by Projects of International Exchange and Cooperation in Agriculture, Ministry of Agriculture and Rural Affairs of China-Science, Technology and Innovation Cooperation in Aquaculture with Tropical Countries along the Belt and Road.

Availability of data and material All data generated or analyzed during this study are included in this published article (and its supplementary information files). If there is any missing, the datasets used or analyzed during the current study are available from the first/corresponding author on reasonable request.

Code availability Not applicable.

\section{Declarations}

Ethics approval This article does not contain any studies with animals performed by any of the authors.

Conflict of interest The authors declare no competing interests. 


\section{References}

Aguiar GP, da Silva JCGL, Frega JR, de Santana LF, Valerius J (2017) The use of constant market share (CMS) model to assess Brazil nut market competitiveness. J Agric Sci 9(8):174-180. https://doi.org/ 10.5539/jas.v9n8p174

Ahmadi-Esfahani FZ (2006) Constant market shares analysis: uses, limitations and prospects. Aust J Agric Resour Econ 50:510-526. https://doi.org/10.1111/j.1467-8489.2006.00364.x

Bo Y, Chen S, Guo-Qin Y (2017) Export characteristics and influencing factors of China's aquatic products in Central and Eastern European Countries. Chin Fish Econ 6(35):55-63 (in Chinese)

Capobianco-Uriarte M, Aparicio J, Pablo-Valenciano JD (2017) Analysis of Spain's competitiveness in the European tomato market: an application of the constant market share method. Span J Agric Res 15(3):e0113. https://doi.org/10.5424/sjar/2017153-10629 (13 pages)

Chen R, Hartarska V, Wilson NLW (2018) The causal impact of HACCP on seafood imports in the U.S.: an application of difference-in-differences within the gravity model. Food Policy 79:166-178. https://doi. org/10.1016/j.foodpol.2018.07.003

Crona BI, Van Holt T, Petersson M, Daw TM, Buchary E (2015) Using social-ecological syndromes to understand impacts of international seafood trade on small-scale fisheries. Glob Environ Chang 35:162-175. https://doi.org/10.1016/j.gloenvcha.2015.07.006

Deng-Jun Z, Ragnar T, Kristin L (2014) China's impact on global seafood markets. Aquac Econ Manag 18:101-119. https://doi.org/10.1080/13657305.2014.903308

FAO (2020a) The state of world fisheries and aquaculture 2020: sustainability in action. Rome. https://doi. org/10.4060/ca9229en. Retrieved from http://www.fao.org/documents/card/en/c/ca9229en. Accessed 22 June 2020

FAO (2020b) Summary of the impacts of the COVID-19 pandemic on the fisheries and aquaculture sector. Retrieved from: http://www.fao.org/3/ca9349en/CA9349EN.pdf. Aaccessed 25 July 2020

Fligenspan FB, Lélis MTC, Cunha AM, Clezar RV (2015) The Brazilian exports of labor-intensive goods in the 2000s: an analysis using the constant market share method. Economia 16:128-144. https://doi.org/ 10.1016/j.econ.2015.03.005

Fojtíková L (2018) China's trade competitiveness in the area of agricultural products after the implementation of the World Trade Organization commitments. Agric Econ Czech 64: 379-388. https://doi.org/ 10.17221/163/2017-AGRICECON

Geetha R, Ravisankar T, Patil PK, Avunje S, Vinoth S, Sairam CV, Vijayan KK (2020) Trends, causes, and indices of import rejections in international shrimp trade with special reference to India: a 15-year longitudinal analysis. Aquac Int 28:1341-1369. https://doi.org/10.1007/s10499-020-00529-w

Gephart JA, Ml Pace (2015) Structure and evolution of the global seafood trade network. Environ Res Lett 10:125014. https://doi.org/10.1088/1748-9326/10/12/125014

Giusti A, Bianchi E, Barontini F, Cripezzi M, Tasselli G, Armani A (2019) Data analysis of official checks on intra-EU seafood trade: a survey on the Italian veterinary office for compliance with EU requirement (UVAC) of Tuscany in three-year period 2014-2016. Food Control 95:274-282. https://doi.org/ 10.1016/j.foodcont.2018.08.016

Hambrey J (2017) The 2030 agenda and the sustainable development goals: the challenge for aquaculture development and management. Retrieved from: http://www.fao.org/3/a-i7808e.pdf. Aaccessed 25 July 2020

Jepma CJ (1989) Extensions of the constant-market-shares analysis with an application to long-term export data of developing countries. In: Williamson JG, Panchamukhi VR (eds) The balance between industry and agriculture in economic development. International Economic Association Series. Palgrave Macmillan, London.1989, pp 129-143 https://doi.org/10.1007/978-1-349-19746-0_6. Retrieved from: https://link.springer.com/chapter/10.1007/978-1-349-19746-0_6

Jing-Jing Y(2015) Research on China's aquatic products export trade in the terms of European Union's SPS measures. Master of thesis, Northeast Agricultural University. (in Chinese)

Jin-Kai Yu, Jian-Qiu M (2020) Social network analysis as a tool for the analysis of the international trade network of aquatic products. Aquacult Int 28:1195-1211. https://doi.org/10.1007/ s10499-020-00520-5

Jin-Ping Xi (2020) Xi Jinping hosts entrepreneurs' symposium and delivers important speech. http:// www.gov.cn/xinwen/2020-07/21/content_5528789.htm. Accessed 1 June 2021

Jinzhuo W, Jingxin W, Wenshu L (2016) Comparative analysis of primary forest products export in the United States and China using a constant market share model. Forest Prod J 66(7/8):495-503. https://doi.org/10.13073/FPJ-D-14-00077

Lin J, Flachsbarth I, von Cramon-Taubadel S (2020) The role of institutional quality on the performance in the export of coconut products. Agric Econ 51:237-258. https://doi.org/10.1111/agec.12552 
Milana C (1988) Constant-market-shares analysis and index number theory. Eur J Polit Econ 4:453-478. https://doi.org/10.1016/0176-2680(88)90011-0

Nasrullah M, Chang L, Khan K, Rizwanullah M, Zulfiqar F, Ishfaq M (2020) Determinants of forest product group trade by gravity model approach: a case study of China. For Policy Econ 113:102117. https://doi.org/10.1016/j.forpol.2020.102117

Natale F, Borrello A, Motova A (2015) Analysis of the determinants of international seafood trade using a gravity model. Mar Policy 60:98-106. https://doi.org/10.1016/j.marpol.2015.05.016

National Development and Reform Commission (2015) Vision and actions on jointly building silk road economic belt and 21st-century maritime silk road. Beijing. Retrieved from: https://en.ndrc.gov.cn/ newsrelease_8232/201503/t20150330_1193900.html. Accessed 25 June 2020. (in Chinese)

Ping W, Tran N, Chan CY, Dao D, Wilson NLW (2018) An analysis of seafood trade duration: the case of ASEAN. Mar Resour Econ 34(1):1-18. https://doi.org/10.1086/700599

Sabau G, Muktadir Boksh FIM (2017) Fish trade liberalization under 21st century trade agreements: the CETA and Newfoundland and Labrador fish and seafood industry. Ecol Econ 141:222-233. https:// doi.org/10.1016/j.ecolecon.2017.04.025

Tyszynski H (1951) World trade in manufactured commodities 1899-1950. Manch Sch 19(3):272-304. https://doi.org/10.1111/j.1467-9957.1951.tb00012.x

Varalakshmi K, Devatkal S (2017) Competitiveness of Indian bovine meat exports-constant market shares analysis. Indian J Anim Sci 87(8):1026-1033.http://www.icar.org.in. Accessed 21 Nov 2020

Wen-Bo Z, Francis JM, Li-Ping L, David CL (2017) A comparative analysis of four internationally traded farmed seafood commodities in China: domestic and international markets as key drivers. Rev Aquac 9:157-178. https://doi.org/10.1111/raq.12110

Widodo T (2010) Market dynamics in the EU, NAFTA, North East Asia and ASEAN: the method of constant market shares (CMS) analysis. J Econ Integr 25(3): 480-500. Retrieved from: www.jstor. org/stable/23000869. https://doi.org/10.2307/23000869

Xiao-Wei W, Zhao-Hui Y, Hui D, Xin-Qiang F, Yong W (2018) Barriers to sustainable food trade: China's exports food rejected by the U.S. Food and Drug Administration 2011-2017. Sustainability 10:1712. https://doi.org/10.3390/su10061712

Xu-Ping C, Shuai Y, Xiang-Meng H, Ju-Xi T (2018) Dynamic decomposition of factors influencing the export growth of China's wood forest products. Sustainability 10:2780. https://doi.org/10.3390/ su 10082780

Yan L, Xunpeng S, Laurenceson J (2020) Dynamics of Australia's LNG export performance: a modified constant market shares analysis. Energy Econ 89:104808. https://doi.org/10.1016/j.eneco.2020. 104808

Yang BX, Anderson JL, Asche F (2020) Determinants of China's seafood trade patterns. Mar Resour Econ 35(2):97-112. https://doi.org/10.1086/708617

Yun-jie C, Jie W (2018) Factors affecting China's export growth of agricultural products to Pakistanfactorization and calculation based on the CMS model. J Xinjiang Univ (Philos Hum Soc Sci) 46(4):10-20 (in Chinese)

Yun-Yun D, Yong-Ming Y, Yuan Y, Zhen Z, Hong-Yan Z (2020) Competitiveness of Chinese and Indonesian tilapia exports in the US market. Aquac Int 28:791-804. https://doi.org/10.1007/s10499-019-00496-X

Yuxiang F, Zheng L (eds) (2006) Fisheries Department, Ministry of Agriculture of the People's Republic of China. Overview of national fishery development. China Fisheries Yearbook 2006,1:27-30. China Agricultural Press, Beijing. (in Chinese)

Zengsheng L, Zheng L (eds) (2007) Fisheries Department, Ministry of Agriculture of the People's Republic of China. Overview of national fishery development. China Fisheries Yearbook 2007,1:911. China Agricultural Press, Beijing. (in Chinese)

Zengsheng L, Zheng L (eds) (2008) Fisheries Department, Ministry of Agriculture of the People's Republic of China. Overview of national fishery development. China Fisheries Yearbook 2008,1:12-16. China Agricultural Press, Beijing. (in Chinese)

Zheng-Xin W, Hong-Hao Z, Ling-Ling P, Tong J (2017) Decomposition of the factors influencing export fluctuation in China's new energy industry based on a constant market share model. Energy Policy 109:22-35. https://doi.org/10.1016/j.enpol.2017.06.050

Zhihui L, Jing S, Han S, Zhiyao S, Zihan W (2020) Do China's wind energy products have potentials for trade with the "Belt and Road" countries? - a gravity model approach. Energy Policy 137:111172. https://doi.org/10.1016/j.enpol.2019.111172

Publisher's note Springer Nature remains neutral with regard to jurisdictional claims in published maps and institutional affiliations. 